\title{
Rosvita de Gandersheim: Teatro e Educação no Século X
}

\author{
Rosvita de Gandersheim: Theater and Education in the 10th Century \\ Rosvita de Gandersheim: Teatro y Educación en el Siglo X
}

Recebido: 14/12/2021 | Revisado: 19/12/2021 | Aceito: 05/01/2022 | Publicado: 08/01/2022

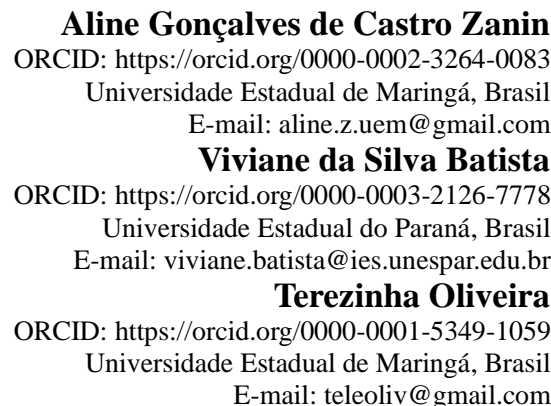

\begin{abstract}
Resumo
Este artigo tem por objetivo refletir sobre o teatro medieval, por meio dos escritos de Rosvita de Gandersheim (9351002). Assim, estudamos a atuação educativa desta personagem feminina do século $X$, monja que viveu em um mosteiro situado, na região do que hoje é a Alemanha. Caracterizada como pesquisa bibliográfica e documental, para a realização deste estudo, analisou-se a trajetória desta personagem por meio das obras: Dramas e Obra dramática. Além dos seus escritos, pautou-se também em autores como Lauand (1986) e Bovolim (2005). Considerando a monja como uma grande intelectual para a história da educação, pois dela chegou até nós oito poemas, seis peças de teatro e dois épicos, sendo todos de cunho religioso. A monja foi uma figura importante para a história do teatro medieval, pois por meio deste instrumento pedagógico ela ensinava conceitos fundamentais da matemática e dramatizava valores éticos e morais do cristianismo primitivo que precisavam ser recuperados. Este estudo foi relevante porque nos possibilitou compreender aspectos e princípios pedagógicos apresentados por esta monja do mosteiro de Gandersheim. Assim, seguindo os princípios da história social, com especial atenção ao conceito de longa duração, este artigo apresenta fundamentalmente, a relevância dessa intelectual para a História da Educação Medieval.
\end{abstract}

Palavras-chave: Teatro medieval; Intelectual feminina; História da educação medieval; Mosteiro.

\begin{abstract}
The present article is meant to think the medieval theatre through the writings of Hrotsvitha of Gandersheim (9351002). At this research we have studied her educational work, while she lived in a monastery in nowadays Germany. Due to its historiographical nature, this is a bibliographic and documental research in which we analyse this character's path through her works: Dramas and Obra dramática. We also work with authors as Lauand (1986) and Bovolim (2005). We consider this nun an intellectual with great relevance to education's history because we have eight poems, six theatre pieces and two epics from her, all of them being religious and pedagogic. The nun was an expressive figure for medieval theatre's history, for she taught, by those means, important concepts of mathematics, also, she dramatized primitive Christian moral and ethical values, that needed to be recovered. So, by social history's precepts, with a special attention to the concept of long duration, we analyse Hrotsvitha of Gandersheim's work as an intellectual from/for the history of medieval education.
\end{abstract}

Keywords: Medieval theatre; Female intellectual; History of medieval education; Monastery.

\section{Resumen}

Este artículo tiene como objetivo reflexionar sobre el teatro medieval a través de los escritos de Rosvita de Gandersheim (935-1002). Así, estudiamos el papel educativo de este personaje femenino del siglo X, una monja que vivía en un monasterio ubicado en la región de lo que hoy es Alemania. Caracterizado como una investigación bibliográfica y documental, para la realización de este estudio se analizó la trayectoria de este personaje a través de las obras: Dramas y Drama. Además de sus escritos, también se basó en autores como Lauand (1986) y Bovolim (2005). Considerando a la monja como una gran intelectual para la historia de la educación, le han llegado ocho poemas, seis obras de teatro y dos epopeyas, todas de carácter religioso. La monja fue una figura importante en la historia del teatro medieval, pues a través de este instrumento pedagógico enseñó conceptos fundamentales de la matemática y dramatizó los valores éticos y morales del cristianismo primitivo que necesitaban ser recuperados. Este estudio fue relevante porque nos permitió comprender los aspectos y principios pedagógicos presentados por esta monja del monasterio de Gandersheim. Así, siguiendo los principios de la historia social, con especial atención al concepto de 
largo plazo, este artículo presenta fundamentalmente la relevancia de este intelectual para la Historia de la Educación Medieval.

Palabras clave: Teatro medieval; Intelectual femenina; Historia de la educación medieval; Monasterio.

\section{Introdução}

O objetivo deste artigo é refletir sobre o teatro no século X, por meio da dramaturgia de Rosvita de Gandersheim (935-1002). Para isso, estudamos suas peças teatrais, pois consideramos que por ser uma obra escrita por uma monja, abadessa do mosteiro de Gandersheim, nos permitirá compreender os princípios pedagógicos apresentados por ela. As obras que nortearam o desenvolvimento de nossas reflexões foram Dramas e Obra dramática, além dos escritos sobre Rosvita dos autores Lauand (1986) e Bovolim (2005).

A fim de ressaltar a importância da historiografia, recorremos à leitura de Marc Bloch (2001), objetivando entender o movimento da história e a relevância da longa duração, destacando a importância da história para compreendermos o homem e suas relações sociais. Conforme aponta Bloch (2001) "Por trás dos grandes vestígios sensíveis da paisagem, [os artefatos ou as máquinas,] por trás dos escritos aparentemente mais insípidos e as instituições aparentemente mais desligadas daqueles que as criaram, são os homens que a história quer capturar" (p. 54).

Partindo desse pressuposto, ao estudarmos a obra de Rosvita buscamos, orientados pela teoria histórica de Bloch (2001), conhecer não apenas o passado, mas o objeto da história, o humano. Considerando a civilização objeto privilegiado do historiador, Bloch (2001) nos ajuda a compreender o homem na sociedade e no tempo. Por meio de seus apontamentos e partindo da mesma perspectiva, refletimos sobre a importância de recuperar autores como Rosvita de Gandersheim, que contribuíram, intelectualmente, para formação humana de seu tempo.

\section{Metodologia}

Para atender ao objetivo de refletir sobre o teatro medieval por meio dos escritos de Rosvita de Gandersheim (9351002), esta pesquisa ancorou-se na análise e na interpretação de produções de estudiosos que discutem a temática e permitem o entendimento dos princípios pedagógicos que vislumbramos nas peças teatrais dessa monja, como Lauand (1986), Carlson (1997), Paz (2000), Bloch (2001), Agostinho (2002), López (2003), Bovolim (2005), Oliveira (2005) e outros.

Portanto, considerando esses autores e o viés histórico da temática discutida, optou-se metodologicamente por uma pesquisa de abordagem qualitativa, de natureza básica, procedimentos bibliográficos e documentais, bem como por objetivos descritivos e explicativos.

Chegou-se a essa decisão porque é na abordagem qualitativa que o pesquisador se vale da indução para descrever a situação analisada, e assim, a pesquisa atinge um caráter exploratório e investigativo apoiado nos procedimentos adotados pelo pesquisador (Cristiane, 2014; Evêncio, Teixeira, Rodrigues, Feitosa, \& Fontes, 2019).

Do mesmo modo, é na pesquisa de natureza básica que visualizamos uma investigação sobre os princípios básicos e as razões para a ocorrência de um determinado evento, processo ou fenômeno, constituindo o que chamamos de pesquisa teórica (Lakatos \& Marconi, 2011).

De acordo com pressupostos teóricos defendidos por Gil (2008) e Will (2012), os procedimentos utilizados na pesquisa devem estar alinhados à natureza e objetivos dela. Por isso, em relação aos procedimentos, este estudo engloba procedimentos bibliográficos, documentais e apoia-se em objetivos que visam descrever um contexto histórico e analisá-lo.

Portanto, a pesquisa é bibliográfica ao passo que a seleção, coleta e tratamento das informações ocorreram por meio de um levantamento de obras bibliográficas sobre a temática e do entendimento dessas obras; é também documental porque se vale da análise de algumas das peças teatrais de Rosvita de Gandersheim (935-1002), entendidas neste estudo como documentos históricos, isso porque entendemos que os documentos "constituem também uma fonte poderosa de onde podem 
ser retiradas evidências que fundamentem afirmações e declarações do pesquisador . . Não são apenas uma fonte de informações contextualizada, mas surgem num determinado contexto e fornecem informações sobre esse mesmo contexto" (Lüdke \& André, 1986, p.39).

Logo, este artigo apresenta a relevância de Rosvita de Gandersheim para a História da Educação Medieval por meio de uma pesquisa que se caracteriza como qualitativa, bibliográfica, documental e histórica - é importante frisar que os procedimentos contemplam a história social porque foram desenvolvidos pela análise dos aspectos sócio-históricos vislumbrados por meio da longa duração (Bloch, 2001).

\section{Resultados e Discussão}

Durante a Idade Média ocorreram muitas invasões na Europa, fato que contribuiu para coexistência de diferentes organizações sociais. Visto que:

coexistiram civilizações com organizações econômico-político-sociais diferentes: as civilizações ocidentais, oriundas do antigo Império Romano do Ocidente; as orientais, oriundas do antigo Império Romano Oriente, como é o caso da civilização bizantina; e as civilizações orientais que não faziam parte do antigo Império Romano, como é o caso da civilização muçulmana e das civilizações da Ásia oriental (Andery, et al., 1999, p. 133).

As civilizações bizantina e muçulmana destacam-se dentre as orientais por contribuir para a divulgação de conhecimentos que foram assimilados e desenvolvidos, posteriormente, pela civilização ocidental. Caracterizadas por ter formação étnico-cultural diversificada (grega, síria, egípcia, persa...), essas civilizações tinham o poder político centralizado, apresentando grande desenvolvimento das cidades e o comércio como uma das principais atividades econômicas (Andery, et al., 1999). Um aspecto que contribuiu para o desenvolvimento do conhecimento foi o contato com outras culturas, isso fez com que as civilizações bizantina e muçulmana ampliassem o conhecimento em diversas áreas, as quais a Europa ocidental teria acesso apenas posteriormente (Andery, et al., 1999).

A Europa ocidental, no século X, foi marcada por uma nova onda de invasões (vikings, muçulmanos, magiares) e pela desordem social. Durkheim (2002) observa que:

O século X, que o antecedera, durante o qual a dinastia carolíngia acabara de morrer, fora para o mundo cristão uma época de dolorosa angústia e de ansiedade geral. Existiam milhares de dificuldades, às quais era preciso fazer frente. Eram os Escandinavos que repetiam as devastações no Norte, eram os Sarracenos que invadiam o Sul, eram os Normandos que ameaçavam todo o litoral. Dentro, o império carolíngio desmoronava-se, despedaçava-se numa poeira de grupos feudais que, mal coordenados entre si, procuravam um modo de organização um tanto estável através de toda espécie de choques e conflitos internos. É um período de luta, de tentativas, de laboriosa adaptação. As sociedades europeias precisavam de todas as suas forças para se defender contra os inimigos de fora e para restabelecer seu equilíbrio interior. Não tinham, portanto, nem tempo, nem liberdade de espírito necessários às obras do pensamento. Assim, o século $X$ foi um século de estagnação intelectual, embora não sem alguma veleidade de reação. O ensino continua sendo dado, é verdade, nas igrejas e nos mosteiros, porém, sem mudança, sem progresso; durante toda essa época, não se assinala nenhum grande nome (p. 69).

De acordo com o autor, no século $\mathrm{X}$ o ensino continua sendo ministrado nas igrejas e nos mosteiros, no entanto, não teria tido grandes avanços. Apesar de o autor afirmar que neste período não se destacou nenhum grande nome, Rosvita foi uma personagem muito significativa para a educação de seu século.

As transformações que ocorreram, neste período, exigiam uma nova educação. Conforme aponta Bovolim (2005), "Com o feudalismo alguns hábitos mudaram" (p.74), inclusive o papel que a mulher passou a exercer, socialmente. Rosvita foi essencial para a formação intelectual feminina do século $\mathrm{X}$, pois as mulheres passaram a desempenhar um importante papel social, além da vida doméstica, elas exerciam funções distintas das que ocupavam anteriormente, elas passaram a ser 
responsáveis pela administração do feudo, representando o marido quando ausente.

Nesse período, a mulher passou a exercer um importante papel na educação, pois competia a ela a instrução dos filhos, administração dos feudos, quando da ausência de seus esposos e pais, administração dos mosteiros, quando religiosas. Esses novos papéis femininos que mulheres passam a desempenhar, justificam, a nosso ver, as razões pelas quais Rosvita educa as mulheres, ensinando-lhes elementos fundamentais de matemática, de música, da natureza e transmitindo também, como não poderia ser de outro modo, os princípios morais e religiosos que norteavam a sociedade naquele momento (Bovolim \& Oliveira, 2018, p. 1006).

Como educadora e cristã, a monja preocupava-se em ensinar as jovens e as religiosas, do seu convento, conhecimentos que considerava necessário para elas. Por presenciar o momento de uma nova realidade para as mulheres, Rosvita de Gandersheim, tinha uma visão ampla em relação à educação que as mulheres de sua época deveriam receber. Este é um dos motivos que levou Rosvita a se inquietar com a educação feminina.

Dentre o período de transição do Império Carolíngio (fins do século IX até meados do século X) para o sistema feudal é preciso destacar a relevância que a igreja teve na formação deste 'novo' homem. Conforme Bovolim (2005):

A igreja, enquanto instituição que, no decorrer dos séculos, foi se fortalecendo, organizando e ocupando espaço significativo na vida dos homens, estabeleceu ordem e regras de conduta para aquela sociedade em condições caóticas e teve um papel fundamental na educação daqueles homens (p. 77).

De acordo com a autora, a Igreja e os mosteiros influenciaram o pensamento e as concepções de vida dos homens que viviam na Europa ocidental, no decorrer do século X.

Rosvita viveu no mosteiro de Gandersheim. Sua origem geográfica, segundo Paz (2000), teria sido a baixa Saxônia, que hoje é a Alemanha. Por vivenciar o período de desconstrução do Império Carolíngio e o início do sistema feudal, Rosvita entendia que as transformações que aconteciam naquele momento, exigiam uma nova educação e um novo comportamento.

Como educadora cristã, a formação dos homens do seu tempo era algo que a inquietava. Em virtude dessa inquietação, Rosvita via no teatro uma estratégia para propagar suas ideias. Ela fundamentou seus estudos retomando autores do teatro pagão e os abordou de maneira original, na medida em que, a partir deles, elaborou suas peças de natureza, eminentemente cristãs. Para López (2003):

É possível que os diálogos de Rosvita sejam, em grande parte, dedicados a ele, talvez para separá-lo de leituras tão perniciosas, que o autor bem sabe que ele só consegue imitando o agradável e delicioso humor terentino, que ela, tudo deve ser dito, deve saber magnificamente (p. 15) ${ }^{1}$.

Rosvita possivelmente escreveu suas peças para as noviças que viviam no mosteiro de Gandersheim. Seu intuito era mantê-las distante de leituras pagãs, pois temia que elas se corrompessem diante do conhecimento de coisas nefastas. Assim, Rosvita justifica o fato de ter imitado Terêncio (185 a.C - 159 a.C), pois enquanto outros o aclamavam - lendo-o com o mesmo gênero de composições com as quais os incestos das mulheres lascivas foram recitados -, a castidade das virgens sagradas era agora celebrada graças à engenhosidade de Rosvita.

Segundo López (2003), a monja muitas vezes se envergonhou por ter que abordar alguns temas, porém ela considerava imprescindível debatê-los.

\footnotetext{
${ }^{1}$ Es posible que los diálogos de Rosvita estén, en buena medida, dedicados a el, quizás para apartarlo de lecturas tan perninciosas, lo cual sabe bien la autora que sólo podrá conseguir imitando el agradable y delicioso humor terenciano, que ella, todo hay que decirlo, debía de conocer magnificamente (López, 2003, p. 15).
} 
Mas se, ruborizando, esqueci esses fatos, não cumpriria meu propósito nem exporia com toda a plenitude de meu poder o louvor dos inocentes, porque, quanto mais a luxúria do insano se arrastasse à tentação, mais sublime glória do Supremo Ajudante e mais gloriosa a vitória daqueles que triunfam sobre essa mesma tentação, especialmente quando a fragilidade feminina supera enquanto a força viril é submetida à confusão (p. 55)².

Supomos, por meio dos escritos de López (2003), que tratar de determinados assuntos era algo desafiador para Rosvita, no entanto, a monja supera a vergonha para alcançar o seu objetivo, a celebração das almas inocentes. Ao agir desse modo, Rosvita foi uma figura importante para a história do teatro medieval, pois por meio desse instrumento pedagógico ela ensinava às crianças e jovens de Gandersheim, conceitos fundamentais da matemática e dramatizava valores cristãos que precisavam ser recuperados.

Como já observamos, a Idade Média (século V ao XV) foi marcada por uma forte influência da Igreja cristã, sobretudo a Europa Ocidental. No entanto, Cambi (1999) nos mostra que o fato não é inédito desse período, pois, desde a Antiguidade, a religião teve forte influência sobre o modo como a sociedade se organizava. Também, Oliveira (2005), observa a relevância da Igreja no processo educativo medieval, visto que:

a Igreja deu aos homens uma possibilidade de convivência baseada nas diferenças e é isso que dá a ela o papel civilizatório; que permite a criação de uma filosofia explicativa das relações humanas. Se assim podemos expressar, foi esse caráter democrático da Igreja que a tornou a grande norteadora da sociedade (p. 19).

De acordo com a autora, essa instituição foi a grande responsável pelo ensino dos valores morais e da boa conduta para viver socialmente. Com efeito, vale destacar que as afirmações de Cambi (1999) e Oliveira (2005), em relação ao papel positivo da Igreja já tinham sido observadas por Durkheim no século XIX.

E a Igreja é que serviu de mediadora entre os povos heterogêneos, ela foi o canal pelo qual a vida intelectual de Roma conheceu uma progressiva transfusão nas novas sociedades que estavam em via de formação. E é precisamente pelo ensino que essa transfusão se realizou (Durkheim, 2002, p. 26).

O autor destaca, também, a importância dos mosteiros no seio da sociedade e os considera como relevantes centros culturais para a preservação do conhecimento profano e sagrado da antiguidade.

Cada vez mais, o cristianismo tornava-se a única civilização onde vinham comungar todas essas sociedades que não tinham uma civilização própria. De alguma maneira, portanto, a Europa estava moralmente mais unificada do que hoje, pois não havia, por assim dizer, nenhuma civilização nacional que pudesse contrabalançar a civilização comum a todos os povos europeus. Isso é, aliás, o que explica o enorme papel cumprido pela instituição monacal na formação intelectual e moral da Europa. Com efeito, o monge não é de país algum, de sociedade alguma, a não ser a grande sociedade cristã (Durkheim, 2002, p. 45).

Com o intuito de combater o paganismo, a Igreja considerava indispensável que não apenas os membros eclesiásticos, mas também os leigos adquirissem certa cultura para compreender as sagradas escrituras. Essas necessidades já eram apontadas no final da Antiguidade por (Santo) Agostinho (2002), que defendia que para ser cristão era importante ter o domínio da matemática, da botânica entre outros conhecimentos considerados relevantes para a formação humana.

Essas eram as necessidades superiores que obrigavam a Igreja a abrir escolas, bem como a abrir nelas um lugar para a

\footnotetext{
2 Pero si, enrojeciéndome, olvidase estos hechos, ni satisfaría mi propósito ni expondría con toda la plenitud de mi poder la alabanza de los inocentes, porque, cuanto más arrastran a caer en la tentación las lisonjas de los dementes, tanto más sublime se muestra la gloria del Supremo Auxiliador y más gloriosa la victoria de los que triunfan sobre esa misma tentación, sobre todo cuando la fragilidad femenina vence mientras la fuerza viril queda sometida a la confusión (López, 2003, p. 55).
} 
cultura pagã. As primeiras escolas desse gênero foram as que se abriram junto às catedrais. Os alunos eram sobretudo jovens que se preparavam ao sacerdócio; mas também eram recebidos simples leigos que não tinham decidido ainda abraçar o santo ofício (Durkheim, 2002, p. 29).

Segundo Durkheim (2002), muitas escolas se instalaram ao lado de mosteiros, nelas eram instruídas todas as crianças independentemente de suas condições e vocações. Gilson (2007), também, indica o modo como o ensino era organizado nas escolas monásticas.

As escolas monásticas compreendiam geralmente a escola interior, ou claustral, reservada aos religiosos do mosteiro, e a escola exterior, na qual eram admitidos os padres seculares. Originalmente, essas escolas foram quase todas vinculadas a mosteiros beneditinos . . . As escolas catedrais (ou episcopais, ou capitulares) organizaram-se bem cedo em torno das igrejas catedrais, sob a direção pessoal do bispo e, por vezes, até com sua colaboração efetiva (Gilson, 2007, p. 227).

Por meio desses autores, é possível depreender como o mosteiro foi relevante para a educação medieval, inclusive, considerado o espaço reservado para o conhecimento. Nele foi conservado e transmitido o conhecimento. Nesse sentido, o fato de Rosvita ter vivido a maior parte da vida em um mosteiro beneditino, contribuiu sobremaneira para a sua formação intelectual.

De acordo com Durkheim (2002), a ordem beneditina foi uma das ordens que mais contribuiu para despertar os estudos no medievo. O autor afirma que:

já no século VI, fixou-se uma ordem que contribuiria mais do que qualquer outra para acordar os estudos. É a ordem dos beneditinos, cujo fundador é São Bento de Núrsia. Não é que São Bento tenha-se proposto defender a causa das letras e da cultura intelectual. Católico ortodoxo, ele subordinava todos os interesses profanos, quaisquer que fossem, aos interesses da fé. Mas, pela força das coisas, ele foi levado a abrir um lugar importante para o estudo na vida monacal. Para não deixar seus monges desocupados, obrigava-os a ativos trabalhos matérias; existem no dia, porém, horas, que variam com as estações, em que esses trabalhos são impossíveis. Esses momentos deviam ser dedicados à leitura. É verdade que, em princípio, o monge só devia ler os livros sacros (p.40).

O autor salienta que o fundador da Ordem Beneditina (c. 529) submetia os interesses profanos aos interesses da fé, vivia uma disciplina severa dedicando-se a atividade intelectual e manual. Por pertencer a essa ordem, certamente Rosvita foi influenciada por esses princípios e essas características ficaram patentes em seus escritos.

O mosteiro de Gandersheim onde Rosvita viveu, foi fundado no ano de 852 e consagrado em 881, o espaço era considerado centro de aprendizado e cultura na Saxônia medieval.

Devemos imaginar o convento de Gandersheim como um espaço cultural de primeira ordem, iluminado em todos os momentos pelo poderoso ideal intelectual, com seu cultivo mental, espiritual e mental, harmonização da vida oratória e contemplativa, amor ao próximo e trabalho social, dedicados a outros (embora, não nos iludamos, devemos considerar também a exploração, pelos religiosos de Gandersheim, dos camponeses que são sujeitos de suas posses feudais), tudo combinado com o estudo ininterrupto e a leitura e releitura dos clássicos, daqueles autores, tanto pagãos quanto cristãos, em cuja obra todo o conhecimento dos templos do passado estava confinado. E devemos também levar em conta as trocas literárias, epistolaristas ou mesmo paroquiais e longas discussões lógicas ou filosóficas, com os intelectuais seculares da época (López, 2003, p. 14) . $^{3}$

\footnotetext{
${ }^{3}$ Hay que imaginarse el conobio de Gandersheim como un espacio cultural de primer orden, alumbrado a todas horas por el poderoso ideal intelectual, con su cultivo anímico, espiritual, mental, con una armonización de vida oratoria y contemplativa, de amor al prójimo y trabajo social dedicado a los demás (aunque, no nos engañemos, también debemos considerar la explotación, por parte de las religiosas de Gandersheim, de los campesinos súbditos de sus posesiones feudales), todo ello combinado con el estúdio ininterrompido y la lectura y relectura de los clásicos, de aquellos autores, tanto paganos como cristianos, en cuya obra se hallaba encerrado todo el saber de los tempos pasados. Y también hay que tener em cuenta los intercambios literarios, epistolares o incluso parrafadas y largas disquisiciones lógicas o filosóficas, con los intelectuales laicos de la época (López, 2003, p. 14).
} 
O autor destaca o papel influente do mosteiro, visto como um espaço cultural de primeira ordem, o mosteiro de Gandersheim foi fundamental na transmissão do saber, conforme assinala López (2003). É necessário considerar o modo como o mosteiro se constituiu, em espaço de escolarização, destinado a atender as demandas sociais, no sentido de suprir conhecimento e comportamentos que não eram comuns ou ensinados em outros espaços. Para entender a intenção de formação humana de Rosvita, é preciso refletir também sobre a importância de conhecer o projeto educacional que se difundia na época, que era formar o cristão, objetivando alcançar a transformação mental e comportamental.

$\mathrm{Na}$ Idade Média, houve um período que o teatro era desconhecido e, inclusive proibido, em virtude da adoção do cristianismo como religião oficial do Império. Posteriormente, a igreja aceita o teatro e sua característica mais expressiva será seu simbolismo com personagens que vão representar as virtudes e os defeitos, tal como as moralidades, observa López (2003, p. 31). A influência da Igreja era tamanha que era perceptível suas características na arte e no teatro. Cambi (1999) afirma que "a atividade teatral, ambos ligados a festividades religiosas e momentos eminentemente comunitários, vinham desenvolver uma função educativa no âmbito da pólis, acompanhando a ação das leis e sublinhando seus fundamentos éticosantropológicos, como ainda o caráter de livre vínculo coletivo" (p. 79).

Desde a Antiguidade, a vida coletiva já era vista como algo educativo, logo o teatro desempenhava função muito importante para a formação e organização da sociedade.

Um dos instrumentos fundamentais dessa educação comunitária é o teatro, a tragédia e a comédia, que é um espelho da comunidade e que enfrenta seus problemas de legitimação das normas e de descrição/ avaliação dos costumes. Assim, o teatro, em Atenas, é "também e sobretudo um lugar de representação das contradições que laceram o corpo da cidade e as consequências de seus membros", referentes a escolha políticas, éticas, psicológicas como ocorre pelo incesto em Édipo Rei ou pelas leis anteriores superiores às da cidade na Antígona de Sófocles, como também pela aceitação do destino na Oréstia de Ésquilo. No teatro, a comunidade educa a si mesma; com a comédia que fustiga costumes, ridiculariza comportamentos, castigat ridendo mores, como dirão os latinos (Cambi, 1999, p. 79).

Embora o teatro tenha sido visto com desconfiança pelos cristãos, na Idade Média ele continua desempenhando a importante função de educar. De acordo com Lauand (1986), "o teatro medieval - como também a Idade Média em geral continua pouco conhecido. Conhece-se, sim, o teatro grego, o latino e o moderno; o medieval, não" (p. 29). Conforme sugere o autor, talvez isso ocorra devido ao preconceito que se tem deste período, "que leva a ignorar tudo o que é medieval, pelo mero fato de sê-lo" (p. 29).

\section{Discussão}

De acordo com Paz (2000), Rosvita é uma das personagens mais ilustres do século X. Considerada a primeira mulher, na história da literatura latina cristã, a escrever o épico (gênero literário de tradição masculina), a monja se destaca devido à singularidade e riqueza cultural de sua obra. No teatro ocidental, não era comum mulheres dramaturgas, isso destaca a relevância de Rosvita, considerada a primeira dramaturga do teatro medieval. Segundo Paz (2000), Rosvita "é cousiderada a primeira escritora dramática alemana e a primeira poeta saxona; tamén foi a primeira que abordou asuntos que non tiñan tradición escrita" (p. 3), ou seja, não era comum naquela época essa composição dramática, ainda mais escritos por uma monja. Conforme aponta Lauand (1986):

Imitar para inverter! Começa Rosvita o prefácio às suas peças registrando o fato de que há muitos cristãos que, pela beleza formal, lêem Terêncio e assim se mancham com o conteúdo vão e imoral dessas peças. E que, por isso, ela ("eu, a voz forte da abadia de Gandersheim") não se furtará ao trabalho de compor um teatro novo: calcado em Terêncio, mas apresentando valores cristãos (e, acrescentaríamos nós, monásticos) (p. 31). 
O autor apresenta as peculiaridades da obra de Rosvita, explicitando o que a diferenciou dos escritos que existiam. Segundo Lauand (1986), a monja "soube perceber que o teatro em si não é mau, soube reconhecer o talento genial de Terêncio" (p. 32).

A abadessa temia que os cristãos fossem contaminados com leituras e peças imorais, por isso compreende, segundo Lauand (1986), a necessidade de adaptar peças para o público cristão. Suas obras eram marcadas pelo senso de humor e simplicidade. Inspiradas nas leituras de autores pagãos como Terêncio e Plauto, seus textos tratavam de temas envolventes, alguns inclusive de conteúdos amorosos.

De acordo com Lauand (1986), "Rosvita é figura de extraordinária importância para a história do teatro: trata-se de nada menos do que do restabelecimento da composição teatral no Ocidente!” (p. 31). Rosvita ficou muito conhecida pelas obras que produziu, "sua obra obteve os mais altos elogios dos homens mais eminentes de seu tempo" (p. 34).

$\mathrm{O}$ autor destaca, ainda, que o teatro medieval não se preocupava com efeitos especiais, mas, sim, com o realismo dos objetos e cenas do cotidiano. Segundo Lauand (1986), o autor Rui Nunes discute sobre as peças de Rosvita, questiona se elas foram encenadas ou se apenas serviram de textos pedagógicos, mas o próprio Nunes (2018), se convence de que foram encenadas. Todavia, Lauand (1986) defende a ideia de que as peças foram encenadas e que, inclusive, tiveram a participação de crianças como personagens, isso seria evidenciado por causa das falas curtas e fáceis para decorar.

Ainda segundo Lauand (1986), Gandersheim via no teatro uma oportunidade de propagar a fé cristã e ainda que não concordasse com alguns temas, ela considerava necessário abordá-los para alcançar o objetivo de celebrar o louvor das almas inocentes, pois em seus escritos quanto maior fosse à sedução dos amantes (as tentações da carne), maior seria a misericórdia do divino.

Inspirada na escolástica, Rosvita escreve em duas de suas peças teatrais sobre as disciplinas do quadrivium: a música e a matemática. Preocupada com a preservação dos bons costumes (valores morais, cristãos e votos de castidade), Rosvita recuperou autores da antiguidade, gregos, romanos e os escritos sagrados, abordando desse modo, temas considerados relevantes para a formação do homem de seu tempo. Apesar de ser a abadessa do mosteiro de Gandersheim, seus ensinamentos não se pautaram somente nas sagradas escrituras, mas teve também como fonte de inspiração outros referenciais teóricos, inclusive autores considerados pagãos. Uma das principais características de sua obra é a união do religioso com o pagão. Esse aspecto é possível de ser observado nas suas peças, carregadas de passagens bíblicas e de autores clássicos da antiguidade latina. Essas semelhanças evidenciam a natureza dessas peças como expressão do pensamento escolástico.

No monastério, a monja escreveu três livros, ao menos que chegaram até nós. O primeiro foi composto por oito lendas "ou relatos haxiográficos em verso" (p. 16), aponta Paz (2000). No segundo livro, ela escreveu seis peças teatrais, denominado por Paz (2000) 'diálogos dramáticos'. O terceiro livro, composto por dois épicos, foi dedicado à abadessa Gerberga, madre superior do mosteiro de Gandersheim e responsável pela formação monacal de Rosvita.

Considerada uma grande teatróloga, seus dramas perpassaram os séculos. Sua obra foi redescoberta por humanistas alemães no século XVI, sendo difundida por todo o mundo no século XVIII. No entanto, é no século XX que o interesse pela monja aumentou, talvez pelas posturas ideológicas e críticas de caráter feministas. Até este século não tinha existido ainda grupos com o nome de Rosvita e estes foram fundados com a intenção de promover e divulgar sua obra, conforme salienta López (2003).

Rosvita escreveu seis peças teatrais, todas de cunho religioso: Conversão de Galicano, general do Exército; Martírio das santas virgens Ágape, Quionia e Hirena; Ressurreição de Drusiana e Calímaco; Queda e conversão de Maria, sobrinha de Abraão; Conversão da prostituta Taís; Martírio das santas virgens Fé, Esperança e Caridade. Em suas peças todos os protagonistas são mulheres, a monja trata suas personagens femininas como belas, fortes e cultas e os homens rudes e ignorantes. Para Rosvita, a mulher em nada fica atrás do homem, ela destaca ainda que as mulheres não são intelectualmente 
inferiores aos homens (Lauand, 1986).

Na peça Martírio das santas virgens: Fé, Esperança e Caridade, traduzida por Lauand (1986), é retratado um período anterior a escola monástica. O enredo narra o drama de uma mãe chamada Sabedoria, e suas três filhas: Fé (12 anos), Esperança (10 anos) e Caridade ( 8 anos), elas eram de origem grega e vão para Roma, quando chegam lá, apresentam-se ao Imperador Adriano. Em um dado momento, ele questiona a idade das crianças e a mãe responde elaborando um problema matemático, assim se o Imperador tivesse o domínio dessa arte certamente saberia responder. Rosvita, ao narrar esse fato, expressa o seu conhecimento das Artes Liberais.

No desenrolar da peça, as três filhas de Sabedoria são torturadas, até a morte, por declararem-se cristãs e não se curvarem a outros deuses. A mãe Sabedoria, após testemunhar a morte das filhas, deseja morrer para estar junto delas e assim o Senhor teria concedido-lhe a morte.

Na peça Conversão de Galicano: general do exército, narra-se a história de um General do Exército que pede ao Imperador Constantino a mão de sua filha Constança como prêmio, caso ele vença a batalha. O Imperador não queria, porém não vê alternativa, pois este general era indispensável para o exército. Desse modo, o Imperador conversa com a sua filha Constança e avisa que ela terá que se casar, mas sua filha tem um plano. Constança sugere que seja imposto a condição de que o general leve na viagem seus primos, João e Paulo. Ela conversa com seus primos e pede para eles que façam o general Galicano se converter ao cristianismo, pois ela acreditava que se ele se convertesse a fé cristã, ele a deixaria em paz, e assim quando voltasse de viagem ela não precisaria se casar com ele e poderia permanecer, então, pura. E assim aconteceu, quando Galicano voltou de viagem ele era um novo homem, agora cristão e assim ele permitiu que Constança permanecesse pura e virgem e ele não se casou com ela. O Imperador Constantino ainda o convidou para viver com eles no império, como recompensa por ele ter ganhado a batalha, porém Galicano recusou o convite, pois temia cair em tentação ao avistar todos os dias sua amada Constança. "Não há tentação que deva ser mais evitada, que o desejo que entra pelos olhos", disse Galicano (López, 2003, p. 70).

A peça A queda e conversão de Maria: sobrinha do ermitão Abraão, narra a história de uma jovem que, após levar uma vida sozinha durante 20 anos, perdeu a virgindade, voltou ao mundo e não temeu misturar-se na companhia das prostitutas. Mas, depois de dois anos, foi levada novamente ao bom caminho graças aos conselhos de seu tio Abraão. Como penitência, durante 20 anos, limpou as manchas de suas faltas com práticas contínuas de jejum vigílias e oração.

Na peça Conversão da prostituta Taís, Rosvita relata a história parecida com a anterior. A prostituta Taís se converte e o ermitão Pafnúcio assinou uma penitência, na qual ela passaria 3 anos numa estreita cela, depois de reconciliada com Deus, Taís dormiu em Cristo 15 dias depois de concluir sua penitência. O interessante dessa peça é que Rosvita inicia o diálogo falando sobre a música, sendo essa uma das disciplinas de sete Artes Liberais que fazem parte do quadrivium.

No Martirio das santas virgens Ágape, Quionia e Hirena, Rosvita narra a história de um governador abusado chamado Dulcídio, ele tenta se aproveitar das três irmãs Ágape, Quionia e Hirena. Diocleciano pede que as três irmãs se curvem aos deuses e lhes ofereçam sacrifícios e elas se negam. Ele, então, ordena que elas sejam presas e torturadas e encaminhadas ao governador Dulcídio. Irene diz que o seu desejo é ser torturada por amor a Cristo. Na calada da noite as jovens estavam encarceradas em uma cela, quando Dulcídio as visita com a intenção de se saciar em seus braços. Mas, assim que ele entrou enlouqueceu e, abraçando bacias e panelas, beijou-os como se fossem donzelas, até que o rosto e as vestes dele ficaram horrivelmente pretos. Em seguida, ele deu ao conde Sisinio o poder de punir as donzelas. Sinisio acabou matando Ágape e Quionia. Surgem então dois anjos que salvam Irene, porém Sisinio ordena que matem-na com flechas. Irene então alerta Sisinio que será condenado por sua maldade e ainda sendo torturada, ela diz que receberá a coroa da virgindade.

Na peça Ressureição de Drusiana e Calímaco, a monja retrata a história de um homem que tenta estuprar um cadáver. Apaixonado por uma mulher casada, Calímaco tenta seduzi-la e declara a Drusiana seu amor, mas ela era uma mulher pura, 
que apesar de casada jamais se deitou com homem algum, nem mesmo com seu esposo. Drusiana sente-se tão mal por despertar o desejo em um homem e também com medo de suas investidas, ela deseja a morte para não cair em tentação. Então ela é picada por uma serpente.

O corpo de Drusiana é encomendado a Fortuanato (coveiro), ele a sepulta em um túmulo de mármore, porém o apaixonado Calímaco, tendo conhecimento, vai até o túmulo e lá Fortunato faz uma proposta pra ele: se Calímaco lhe pagar um bom dinheiro, ele dá o corpo de Drusiana para Calímaco abusar como quiser. Calímaco aceita, porém antes que abusassem dela, uma serpente saiu da cova de Drusiana e picou os dois, Forturnado e Calímaco. O enredo não termina deste modo, há ainda a ressurreição dos mortos para apuração dos fatos, no entanto a peça se encerra com a morte do coveiro Fortunado, que morre pela segunda vez devido à inveja e soberba que carregava consigo.

Essas sínteses das peças teatrais de Rosvita permitem refletir sobre a formação humana. Ao formar o cristão, a monja estava formando o humano, aquele que está inserido na sociedade. Por meio de suas peças, Rosvita apresenta a realidade, mostrando como os homens são capazes de atrocidades por não possuir o conhecimento, apresenta também a resistência dos que o possuem.

Analisar o passado de figuras históricas como Rosvita de Gandersheim nos faz compreender com mais consciência a função social e educativa que a arte e o teatro desempenham hoje no ambiente acadêmico e escolar. Autores contemporâneos como Soares (2019), Santos, Souza e Derossi (2020) e Machado, Geraldo e Lacorte (2021) e Serpa, Machado, Nascimento, e Almeida (2021) estudam, defendem e apontam a importância da arte teatral dentro do âmbito pedagógico, educacional.

Soares (2019), por exemplo, ao estudar o teatro como um aliado da educação básica pontua que o "teatro enquanto estrutura pedagógica contribui com o desenvolvimento amplo dos indivíduos, pois incide no cognitivo e também no emocional, isso implica dizer que o teatro assume lugar de suma importância na educação" (p. 8). Santos, Souza e Derossi (2020) promovem discussões acerca da potencialidade do teatro na formação docente em química, evidenciando o teatro como instrumento formativo nas mais diversas áreas do conhecimento. Machado, Geraldo e Lacorte (2021) corroboram com essa discussão ao analisarem o uso do teatro como ferramenta de ensino no curso técnico em agropecuária. O mesmo se pode dizer de Serpa, Machado, Nascimento, e Almeida (2021) que trazem em seus escritos a reflexão da necessidade de uma educação a favor da práxis, isto é, da ação, educação e cultura.

Os estudos promovidos pelos autores citados acima nos levam a compreender a relevância em conhecer as origens do teatro e, portanto, aqueles que o promoveram com finalidade pedagógica, como é o caso de Rosvita de Gandersheim.

\section{Considerações Finais}

Logo, o desenvolvimento desse estudo possibilitou pensar nos escritos de Rosvita de Gandersheim, observando como eles foram fundamentais para orientar a sociedade do século X, que estava em processo de transformação. Estudar sua obra nos fez refletir sobre o teatro na Idade Média e a importância do mosteiro para a formação do homem medieval.

Ao apresentarmos a relevância dessa intelectual para a História da Educação buscamos apontar assim a sua contribuição para a educação do século décimo, pois ao apropriar-se do teatro como uma ferramenta pedagógica para ensinar, Rosvita pôde não só viver, mas também transformar a sua realidade. Por perceber a importância desse estudo, sugerimos a quem possa interessar a pesquisa no campo da medievalidade, principalmente no que tange a arte teatral, seus preceptores e sucessores.

Nesta pesquisa, revelamos também a importância da história, na perspectiva da longa duração, pois por meio dela podemos conhecer o passado e o modo como a sociedade se organizava. Conforme aponta Lauand (1986), "só quem ignora as fontes medievais pode ainda imaginar essa época como carrancuda" (p. 38). Nesta passagem, o autor indica que, no decorrer da Idade Média houve, sim, fatos considerados importantes e por isso este período não pode ser considerado como período de 
escuridão - aliás, aproveitamos para sinalizar nosso interesse na continuação dos estudos voltados para essa temática histórica medieval com vistas ao papel social desempenhado por Rosvita de Gandersheim, isso porque acreditamos que ainda há muito o que se discutir a respeito das influências dessa monja na sociedade medieva.

Assim, concluímos nosso estudo, destacando a relevância da Antiguidade e do Medievo para a compreensão da formação do homem contemporâneo, na medida em que consideramos, tal como Bloch (2001), a história como ciência dos homens no tempo.

\section{Referências}

Agostinho. (2002). A Doutrina Cristã. São Paulo: Paulus.

Andery, M. A., Micheletto, N., Sério, T. M., Rubano, D. R., Moroz , M., Pereira, M. E., . . . Zanatto, M. d. (1999). Para compreender a ciência: uma perspectiva histórica (8 ed.). Rio de Janeiro; São Paulo: Espaço e Tempo.

Bloch, M. L. (2001). Apologia da história ou o ofício de historiador. (A. Telles, Trad.) Rio de Janeiro: Jorge Zahar.

Bovolim, Z. Z. C. P. (2005). A proposta educacional de Rosvita de Gandersheim no século X. http://www.ppe.uem.br/dissertacoes/2005-Zenaide_Zago.pdf.

Bovolim, Z. Z. C. P. \& Oliveira, T. (2018). Os escritos de Rosvita de Gandersheim no século X. In: 27 Encontro de Iniciação Científica. UEM. http://www2.faced.ufu.br/colubhe06/anais/arquivos/89ZenaidePolidoBovolim_TerezinhaOliveira.pdf

Cambi, F. (1999). História da Pedagogia. (Á. Lorencini, Trad.) São Paulo: Fundação Editora da UNESP (FEU).

Carlson, M. (1997). Teorias do Teatro. Estudo histórico - crítico dos gregos à Atualidade. (G. Souza, Trad.) São Paulo: UNESP.

Cristiane, M. M. (abril-junho de 2014). Abordagens e procedimentos qualitativos: implicações para pesquisas em organizações. Revista Alcance, 21, núm. 2, 324-349.

Duby, G. (1992). O ano mil. (T. Matos, Trad.) Lisboa: Edições 70.

Durkheim, E. (2002). A evolução pedagógica. Porto Alegre: Artmed.

Evêncio, K. M., Teixeira, S. L., Rodrigues, K. G., Feitosa, F. A., \& Fontes, W. J. (outubro de 2019). Dos Tipos de Conhecimento às Pesquisas Qualitativas em Educação. Rev. Mult. Psic., 13, n. 47, 440-452. doi:10.14295/idonline.v13i47.2105

Geraldo, A., Machado, L. C., \& Lacorte, G. A. (s.d.). Uso do teatro como ferramenta de ensino no curso técnico em agropecuária: um estudo de caso. Research, Society and Development, v. 10, n.3, . doi:ISSN 2525-3409 |DOI: http://dx.doi.org/10.33448/rsd-v10i3.12449

Gil, A. C. (2008). Metodologia do Ensino Superior (4 ed.). São Paulo: Atlas.

Gilson, E. (2007). A Filosofia na Idade Média (2 ed.). (E. Brandao, Trad.) São Paulo: Martins Fontes.

Lakatos, E., \& Marconi, M. (2011). Metodologia do trabalho científico (4 ed.). São Paulo: Atlas.

Lauand, L. J. (1986). Educação, teatro e matemática medievais. São Paulo: Perspectiva.

López, A. J. (2003). Dramas: Rosvita de Gandersheim. Madrid: Ediciones Akal, S.A

Lüdke, M., \& André, M. E. (1986). Pesquisa em educação: abordagens qualitativas (2 ed.). São Paulo: EPU.

Nunes, R. A. (2018). História da Educação na Idade Média (2 ed.). Campinas: Kírion.

Oliveira, T. (2005). Escolástica. São Paulo: Mandruvá.

Paz, X. C. (2000). Obra dramática: Rosvita de Gandersheim (1 ed.). Universidade da Coruña: Servizo de Publicacións.

Santos, V. A., Sousa, R. S., \& Derossi, I. N. (s.d.). A potencialidade do teatro do oprimido na formação de professores de Química . Research, Society and Development, v. 9, n.8. doi:ISSN 2525-3409 | DOI: http://dx.doi.org/10.33448/rsd-v9i8.5753

Serpa, L. G., Machado, C. J., Nascimento, G. A., \& Almeida, A. R. (s.d.). Por uma educação a favor da práxis: ação, educação e cultura. Research, Society and Development. doi:ISSN 2525-3409 |DOI: http://dx.doi.org/10.33448/rsd-v10i1.12104

Soares, A. C. (2019). O teatro como um aliado da educação básica. Research, Society and Development,, v. 9, n.2, 1-15. doi:ISSN 2525-3409 | DOI: http://dx.doi.org/10.33448/rsd-v9i2.2232

Will, D. E. (2012). Metodologia da pesquisa científica. Livro digital (2 ed.). Palhoça: Unisul Virtual. 